\title{
THE RELATIONSHIP BETWEEN PSYCHOLOGICALI CAPITAL AND READINESS FOR CHANGE ON THE TRANSFORMATION PROGRAM OF STATE OWN COMPANY AND PRIVATE COMPANY IN JABODETABEK AREA: LEADERSHIP STYLE AS MEDIATOR
}

\author{
${ }^{1}$ Silverius Y. Soeharso and ${ }^{2}$ Kristiana Dewayani \\ ${ }^{1,2}$ Pancasila University
}

\begin{abstract}
Purpose - This research aimed to examine whether the leadership style mediated the relationship between psychological capital and readiness for change in the process of organizational transformation of state-owned and private companies in Jabodetabek, Indonesia.

Design/methodology/approach - A survey was conducted on 149 employees from 256 private companies and state-own company's. There were three instruments used: the scale of readiness for change from Hanpachern et.al (1997) and Armenakis et.al (1999; 2013), the scale of psychological capital from modified by Dewayani (2014), and the scale of leadership (transformational and transactional) from Bass and Riggio (2006). All three of these measurement scales have strong reliability scores between .82 to .91 . The data were analyzed by SEM (Structural Equation Modeling) and the STATCAL statistical program.

Findings - The research's results revealed that the perception of employee self-leadership fully mediated the relationship between psychological capital and readiness for change.

Originality/value - It is suggested that in a process of transformation, the role of both the transactional and transformational leadership styles is important, but transformational leadership has a more significant influence in the process of organizational transformation. Although the theory and previous studies have stated that transformational leadership is more significant than transactional leadership in the process of organizational transformation, this research shows the level of position in the organizational hierarchy also influences. This research shows that at the staff level especially sacrificed proves that the transactional leadership style is more influential than the transformational
\end{abstract}


leadership style. Thus, in the process of organizational transformation, both leadership styles need to be applied depending on the group of employees that will be influenced. The lower the position, the more the need to apply transactional leadership style, the higher the position the possibility of the need for transformational leadership style.

Practical Implications: From the description above, readiness for change can be interpreted as psychological and physical readiness, to understand the need for changes needed by the organization, individual beliefs to be able to implement planned or proposed changes and to believe that these changes can have a positive impact, both for themselves and organization.

Research limitation: The sample size is too small to generalize the findings to the larger population. In addition to samples that are too small to be generalized to a larger population, this research also only involves samples in Jabodetabek so that it is less representative of the population in Indonesia, other than that it is only taken from the staff level so that the managerial level is not examined in this research.

Research Type Research paper.

Keywords: Leadership, Psychological Capital, Readiness for Change, Indonesian Companies.

\section{INTRODUCTION}

Globalization requires each organization and business people (entrepreneurs) to be able to deal with and adapt to various pressures, particularly from the external environment and internal problems daily. Only organizations that are able and quickly adapt to internal and external changes could survive and develop in the long run. One method that can be done to deal with these changes is through an organizational transformational program. The word "transformation" of organizations, especially in the environment of business organizations of State-Owned Enterprises (BUMN) and private companies has often been discussed and implemented since the last decade (Giovanita, Mangundjaya, 2017; Ghany, 2014; Hendrickson \& Gray, 2012).

Organizational transformation is about a comprehensive change in organizations such as financial restructuring, operations, organizational structure, organizational culture, the presence of new technologies, business processes, management systems, service systems or new 
products, implementation of new programs, re-engineering, and so forth. The essence of the transformation process is changing. From the perspective of business psychology, what must be changed is related to the human being, i. e., the mentality, work attitude, and work ethic, while other resources will adjust what is planned, implemented, and evaluated by the HR department.

Problems arise when people in the organization feel "threatened" and becoming "victims" of this change process, yet, a number of questions come up. People are wondered of why should I have to change or what's in it for me? Some members of the organization feel that they are no longer needed or will even have difficulty in adjusting themselves back to the changes that occur. They are reluctant to change since they have already been in their comfort zone psychologically, physically, and even in their work environment (Mangunjaya, 2014, 2017; Bamberger, 2004). Some members of the organization feel that they are no longer needed or will even have difficulty in adjusting themselves back to the changes that occur, basically they are reluctant to change because they are in a comfort zone psychologically, physically, and even in their work environment. Though it could be the work environment that causes the inefficiency of the work process so far (Verdugo \& Loon, 2017).

On the other hand, for the organization's management, comprehensive changes must be made to save the organization in dealing with future challenges. Therefore, the operations of the company/organization can continue in the long run. As a human being, the leadership of organization management is also not immune to the feeling of "fear of failure". Previous experiences show that not the whole organizational transformation planning programs succeeded, even more, many of them failed. Therefore, the readiness to undergo changes made by the organization becomes very important for the success of a transformation (Yip \& Hensmans, 2012).

Companies that cannot transform will suffer even bankruptcy losses due to the inability to adapt to their new environment. For 
example, Kodak, Nokia, Blackberry, Adam Air, and many more, were destroyed by their competitors, new technology, or having the accumulated debt. This is all due to the inability to keep up with environmental change thus, the company might have abandoned its customer's demands. Therefore, the though the company's leaders have to transform the organization in order to run, to adapt, to grow, and sustain in the long run.

From the perspective of business psychology, the transformation focus is human capital. The productive and adaptive human resources toward changes can be the prime mover of the organizational transformation process. Shin et al. (in Soumyaja, Kamalabhan, \& Bhattacharyya, 2018) have confirmed that employee attitudes and behavior in connection with change were crucial for success. The keyword of successful organizational transformation is readiness for change. Each individual needs to leave the comfort zone to a state that is expected to be better than at present. Readiness to deal with organizational change is a form of beliefs, attitudes, and intentions of members toward the organization. Related with the extent to which some changes are needed by the organization and how much capacity of the organization can successfully make changes, either refusing or supporting to contribute to the changes carried out (Armenakis in Radian \& Mangundjaya, 2019). Besides, readiness to deal with organizational changes is interpreted as a form of confidence in employees that can implement the proposed changes. Proposed changes are appropriate for organizational conditions where the existence of management supports these changes has benefits for members of the organization (Holt et al., 2007).

Readiness for change is also defined as the extent to which employees can have a positive view of the organization's need to make changes and the extent to which employees believe that these changes tend to have positive implications for themselves and the organization (Jones et al., 2005). Several factors influence individuals to have readiness in facing changes in their organizations (Cunningham et al., 
2002), such as the dimensions of active-passive work and social support. According to Karasek and Theorell (in Cunningham et al., 2002), work with low demands and decision making is defined as a passive dimension while the seven active dimensions increase employee's opportunities to learn and contribute to the pressure that is obtained to increase motivation and shape new behavioral patterns. The change starts from within the individual himself. Huy in Fachruddin \& Mangundjaya (2012) found several other factors that influence an individual's readiness to change. These factors include a trust for change support and a favorable organizational environment. Meanwhile, Hanpachern, Morgan, and Griego in Madsen et al., In Lizar., et al (2015) found employee knowledge and skills, organizational culture, interpersonal relationships at work, and the relationship between employees and management or leaders also positively influenced readiness individuals for change.

In a case study research conducted by Saragih (2015) 47 individual attributes related to readiness for change, which was then grouped into nine categories. The individual attributes that most often emerge are: challenging the process and modeling the path (transformational leadership); contingency rewards (transactional leadership); spiritual (life experience); hope (psychological capital), continuation (organizational commitment), extraversion (leader nature), awareness (follower nature), altruism (leader value), and courage (follower value).

One individual factor that influences readiness for change is the extent to which HR has good psychological capital to become active subjects and plays a positive role in the process of organizational change. Psychological capital is a condition where an individual has self-efficacy in order to survive in facing a challenge/problem, have an attitude of optimism that he will succeed now and in the future, pursue the goals/expectations of the individual to be successful and successful and have mental endurance (resilience) to be able to survive in a situation of pressure or surpass it so that it can achieve success (Luthans et al, 2007). 
Psychological capital is defined as a condition where an individual can change his condition. From conditions that "how we and our environment know about ourselves" become "who we are and what we want" (Luthans et al., 2007). Psychological capital has the function of making an individual's life more productive, useful and realizing his potential, and focusing on what is happening with him now rather than trying to correct what is wrong with that individual (Luthans and Youssef, 2004). Individuals who have high psychological capital will be more positive and productive in facing life's difficulties and challenges compared to those who have low psychological capital. Psychological capital is a positive psychological state that is characterized by having the confidence to complete challenging tasks, making positive attributions about current and future success (optimism), persevering in achieving goals, and if necessary directing the path to goals expected (hope), and when hit by problems or difficulties, able to survive and rise again even better to achieve the desired success (resilience) (Luthan, Youseef, and Avolio in Nelson and Cooper, 2007).

To deal with organizational changes as described previously, psychological capital can affect the readiness of employees in dealing with changes in their organizations (Ming-Chu and Meng-Hsiu, 2015). Psychological capital and positive emotions can ward off dysfunctional attitudes and behaviors (such as breaking away from groups/disengagement, cynicism, and deviant behavior) that can hinder the progress of change in the organization (Avey et al., 2008). Psychological capital is also an important part of shaping the employee's readiness response to change because readiness is formed not only from how individuals see the condition of their organizational environment but also they need to prepare their psychological resources in dealing with these changes (Kirrane et al., 2017). Jabbarian and Chegini (2017) found that psychological capital has a positive influence on individual readiness in the face of change. This indicates that if the level of psychological capital is high in the individual, it will have an impact on the increased readiness of individuals as well as facing organizational change. Research findings of Fachruddin \& Mangundjaya (2012) also found that 
psychological capital as part of an individual aspect positively influences an individual's readiness to change.

Elastriana (2012) found that there was a significant negative relationship between psychological capital and intention to leave on nurses. That is, the higher the psychological capital a person has, the lower the intention to leave work or organization. Meanwhile, Avey, Youssef, and Luthans (2009) explained that the characteristics that build psychological capital influence each other so that this construct is better measured as a whole. When employees have expectations/goals, selfefficacy, resilience, and optimism that are followed by positive emotions, employees will feel more confident to face the challenges of organizational change where all of these factors are part of psychological capital. Lizar, Mangundjaya, \& Rachmawan (2015) research results show that individual aspects such as psychological capital and psychological empowerment have a positive influence on employees for change. In addition, the results also show that the effect on an individual's readiness for a change compared to psychological capital. This finding supports previous research which found that individual factors, especially psychological capital and employee empowerment influence individual readiness for change.

This research examines the extent to the influence of psychological capital on the readiness of change in the process of organizational transformation in several types of companies in Jabodetabek. In addition to the two variables above from various studies also found the existence of other factors that also influence the process of organizational transformation, one very important factor is leadership. Leadership has an indirect effect on Psychological Capital (Olaniyan \& Hystad, 2016). An authentic leader figure will increase job satisfaction while reducing job insecurities and intention to quit between employees. Leadership also has links to Psychological Capital and burnout (Spence Laschinger \& Fida, 2014). The results support the protective role of organizational and 
intrapersonal resources against fatigue, work dissatisfaction, and mental health.

In the process of transformation, strong support is needed from the presence of effective leadership. Without effective leadership, organizational transformation cannot run optimally. The role of a leader is expected to coordinate, organize, and oversee the transformation process that is being carried out. According to Holten \& Brenner (2015) leadership style is positively related to the three elements of manager involvement, namely participation, information delivery, and commitment.

Effective leadership is strongly dependent on complex patterns of interaction between leaders, followers, and the situation at hand. In general, a successful leader will fulfill charismatic and instrumental two roles. The first role is called the charismatic role while the other role is called the instrumental role (Yukl, 2003). Charismatic roles include how a leader must have the power to imagine or imagine the goals or "dreams" that will be achieved (envision); the ability to empower others (empower) and be able to provide positive energy, spirit, and enthusiasm (energize) for followers to motivate them. At the same time, every effective leader must fulfill an instrumental role by being an organizational designer, controlling, rewarding, and having proper and proportional respect for behavior. According to Ul-Haq \& Kuchinke (2016), different leadership styles bring different consequences, which have a direct or indirect impact on employee attitudes and behavior. Puspasari, Sukmawati, \& Sumertajaya (2017) said that a proactive leadership style that motivates employees will lead to increased employee participation in change programs and ultimately can increase employee readiness in facing changes in the business environment.

Heraclitus, a Greek philosopher who lived 26 centuries ago, said that nothing does change except change itself (Nothing endures but change). The same thing was stated by Sir Winston Churchill, GBR Prime Minister "there is nothing wrong with change if it is in the right 
direction". No exception for business organizations, an organization must be able to change and adjust itself to adopt technological developments, accommodate government policies/regulations, and meet the wishes of its stakeholders or other changes that require adjustments in organizational management if he wants to continue to exist and sustainable. Because change is inevitable, what must be prepared is the mental attitude of HR both employees and leaders of the company to be able to pass through these changes successfully and guarantee the company's operations in the long run.

Readiness for change is a form of beliefs, attitudes, and intentions of members of the organization about the extent to which a change is needed by the organization and how much capability the organization can successfully make changes, both refusing or supporting to contribute to the changes carried out (Armenakis et al. in Radian \& Mangundjaya, 2019). What distinguishes readiness for change from resistance to change is if the readiness is an individual's behavior before facing change while resistance appears as an individual activity trying to stop or delay changes that will be applied in the organization (Armenakis and Bedeian, 1999).

Whereas Hanpachern, Morgan, and Griego (1998) define readiness for change as the extent to which individuals are psychologically or physically ready to face and encourage change in organizations. In addition, readiness to deal with organizational change is interpreted as a form of confidence in employees that they are able to implement the proposed changes, proposed changes are appropriate for organizational conditions, the existence of management support and these changes have benefits for members of the organization (Holt et al., 2007; Kotter, 2003). Readiness for change is also defined as the extent to which employees can have a positive view of the organization's need to make changes and the extent to which employees believe that these changes tend to have positive implications for themselves and the organization (Jones et al., 2005). 
From the description above, readiness for change can be interpreted as psychological and physical readiness, to understand the need for changes needed by the organization, individual beliefs to be able to implement planned or proposed changes, and to believe that these changes can have a positive impact, both for themselves and organization. We want to know the extent of the influence of transformational leadership on the influence of psychological capital with the readiness for change, while in model 2, we want to see the extent of the influence of transactional leadership on the influence of psychological capital on the readiness for change. Furthermore, it will be compared which leadership styles are more effective in influencing psychological capital to the readiness for change (Bacharach, Bamberger, \& Sonnentuhl, 2004).

\section{Hypothesis Development}

\subsection{Psychological Capital and Readiness for Changes}

Change is something that certainly occurred due to the changes of customer demand, new technology, or globalization, therefore every company, organization, or businessman (entrepreneurs), and also employees must have the readiness for change. Readiness for change defined as psychological and physical readiness, a form of individual understanding of the changes needed by the organization, individual belief in being able to implement planned/proposed changes, and belief that these changes can have a positive impact, both for themselves and the organization (Armenakis et al., 1993; Hanpachern et al., 1998; Jones et al., 2005; Holt et al., 2007). According to Meaney and Pung (2008), organizational change planning needs to be carried out correctly because a survey they had conducted on 3199 company executives found that only one-third of respondents said that the company had reached the stage of actual change. Leonard, Lewis, Freedman, and Passmore (2013) show two-thirds of company change projects usually ended in failure.

To deal with organizational change, individuals need to prepare their own psychological resources for dealing with change (Kirrane, 2017). According to Luthans, Avey, Avolio, and Peterson (2010), psychological Vol. 28, No. 3 December 2020

(C) Centre for Indonesian Accounting and Management Research Postgraduate Program, Brawijaya University 
capital is a psychological resource that is not limited to humans and can be increased and developed by the individual itself to achieve success in achieving its goals. According to Ming-Chu and Meng-Hsiu's research (2015), psychological capital has a relationship with the readiness of employees in facing changes in their organizations.

$\mathrm{H}_{1}$ : Psychological capital directly influence a relationship with readiness for change.

\subsection{The Mediating Effect of the Leadership Style}

Since the current research aims to examine the role of the Leadership style in mediating the relationship between psychological capital and readiness for change, this research will focus on the concept of psychological capital as something that can be considered to make an individual's readiness in dealing with change. Rafferty, Jimmieson, and Armenakis (2013) argue that employees who are ready to deal with organizational change produce behavior that is supportive of change, positive work attitudes, and commitment to the organization. Employees who have low readiness for change will view change as undesirable and need to be avoided, have confidence that the organization is not capable of making changes successfully, even refusing to participate in the planning process of implementing change. In the context of organizations that are experiencing a crisis or organizations that require major changes, the role of the leader is considered as the most important role in directing the organization to achieve its goals (Jones, 2004).

Kirrane (2017) research results also state that the impact of management support for change becomes stronger when employees have a strong level of psychological capital as well. Abbasi's research (2017) found that one of the factors related to an individual's readiness for change is transformational leadership. Research conducted by Veronika \& Prihatsanti (2017) shows subordinates' assessment of the relationship established between leaders and subordinates influences attitudes for change. 
$\mathrm{H}_{2}$ : Transformational leadership mediated the relationship between psychological capital and readiness for changes among employees of state-owned and private companies in Jabodetabek.

$\mathrm{H}_{3}$ : Transactional leadership mediated the relationship between psychological capital and readiness for changes among employees of state-owned and private companies in Jabodetabek.

\section{METHOD}

\subsection{Participants and Procedure}

A cross-sectional research design utilizing a quantitative research method was used to pursue the aim of this research (Gravetter \& Forzano, 2009). The participants were employees selected from two types of companies, the private sector and state-owned company at a different organizational level within Jakarta, Bogor, Depok, Bekasi area in Indonesia.

Participation voluntary and confidentiality was maintained. The convenience sample consisted of 149 of the initial target population of 256 . A response rate of $64.25 \%$ was obtained. There were no additional requirements for the sample population other than participants being employed and holding the current employment for at least three years. Therefore, any working employee from two purposive companies (private and state-owned bank) di Jabodetabek area in the Java island, Indonesia, could voluntarily have participated in the research. The participants held an indifferent level of job position, a manager level, coming from both state and private-owned companies that are undergoing an organizational transformation. They are directly involved in the process of organizational change from the beginning of the transformation to the end. Considering the area coverage, the SOEs and Private companies to be investigated are limited to the Jabodetabek area in Indonesia and the transformation program is not more than five years back when the research was conducted. It is intended that the memory of the experience of making the 
slightest change in the transformation process in the organization where the respondent works are still well remembered. The working period of respondents above 3 years with consideration of ensuring that the respondents experience the process of change that is directly carried out in their organization.

Men made up 51 participants $(34.20 \%)$ of the sample, whilst women made up 98 participants $65.80 \%$. The average age of the participants was between 21 and 30 years $(77.2 \%)$, whereas $20.1 \%$ were between the ages of 31 and 35 years above. Most of the participants held a four-year bachelor's degree (70.5\%), 18.1\% had a three-year bachelor's degree (Diploma 3) and $11.4 \%$ held a basic high school qualification.

Human resources managers from both organization types (state and private-owned) were approached. The purpose and objective of the research were explained as well as the data analysis procedure. Further, how the data was to be used was discussed. Upon their consent a generic was sent to the HR department manager (the person responsible for forwarding the email to the participants) explaining: the objectives, importance, and outcome envision for the research, the data collection procedure, that participation is voluntary and anonymity is assured and that the research project will adhere to ethical principles as outlined by the Faculty of Psychology, University of Pancasila, Jakarta Indonesia.

By non-probability sampling, that is the accidental sampling used in this research. This technique has a certain criterion but is taken arbitrarily (available) and easily accessible (Guilford \& Fruchter, 1978). Refer to Kerlinger and Lee (2000), The advantage of accidental sampling allows us to obtain samples in large amounts and faster. However, this technique also has a weakness, which the results cannot be generalized broadly. In this research, we used close-ended questions so that respondents must choose one answer that suits their original condition. By sending the email (google form), researchers inform the participants of a link to a secure webpage where participants could complete the biographical questionnaire, readiness for change scale, psychological 
capital, and leadership styles questionnaires. Clear instructions accompanied this email and necessary contact information for the researchers was made available to the participants to deal with problems or explain in the event of uncertainty. By using the link, the participants accepted the terms of the research, which were also explained to them. This included awareness of the research purpose of the research and a promise that the information would not be used in a harmful manner. Upon completion, the answers are automatically downloaded into an Excel spreadsheet.

\subsection{Measures}

A biographical questionnaire was administered to participants and comprised basic information regarding gender, the city of stay, age, and level of education.

The scale of readiness for change from Hanpachern et.al (1997) and Armenakis et.al $(1999 ; 2013)$ was used to measure the readiness for change level of employees. The readiness for change scale consists of fourteen (14) items. The items are scored on a five-point frequency scale ranging from 1 (very unlikely) to 5 (very likely). The readiness for change scale is further divided into four sub-scales: promoting, participating, personal valence, and change efficacy. Examples of the statement include "My willingness or openness to...' work more because of the change is..."(1-5); '...find ways to make the change fail is (reversed)" (1-5); '...support change is...'(1-5). Dewayani (2014) found a Cronbach's alpha coefficient of 0.82 for the readiness for change scale in a sample of 203 employees working in the cities of Jakarta, Depok, and Surabaya, Indonesia.

The psychological capital questionnaire (Luthans et al., 2007) modified by Dewayani (2014) was used to measure psychological capital. The psychological capital scale consists of twenty-four (24) items. The items are scored on a five-point frequency scale ranging from 1 ("strongly agree") to 5 (strongly disagree). The psychological capital scale is further divided into four sub-scales: hope, efficacy, resilience, and optimism, with 
each component assessed by six items. These items measure the degree of the high or low desire of individuals to change their conditions so that they can achieve success as shown by the scores obtained from the psychological capital questionnaire (PCQ) (e.g. a sample item for assessing the hope facet is "I can think of many ways to reach my current goals. A sample efficacy item is "I feel confident in representing my work area in meetings with management." Optimism is measured with items such as "I'm optimistic about what will happen to me in the future as it pertains to work" and a sample resilience item is "I can get through difficult times at work because I've experienced difficulty before." In this research the reliability of measurement instruments can be produced as follows: To assess the overall construction of the resulting PsyCap, Cronbach's alpha $=0.88,0.89,0.89$, and 0.89. Each subscale was also evaluated: expectations $(0.72,0.75,0.80,0.76)$, efficacy $(0.75,0.84,0.85$, $0.75)$, optimism $(0.74,0,69,0.76,0.79)$, and resistance $(0.71,0.71,0.66$, 0.72). The authors acknowledge the level of sub-standard internal consistency obtained on the optimism scale of the second sample (0.69) and the durability scale of the third sample $(0.66)$ but note the reliability of the overall PsyCap construction in all four studies. Given that overall PCQ scores (Cronbach Alpha scores 0.86) are more reliable than individual subscales, this research uses overall PCQ scores.

The transformational and transactional leadership instrument was used is the Multifactor Leadership Questionaire (MLQ) taken from Bass and Riggio (2006). This questionnaire was developed to measure the extent to which a leader exhibits a transformational or transactional leadership style and to what extent subordinates feel that the leader's role in the process of organizational change will be more comfortable if it is under the control of transformational or transactional leadership. The transformational leadership style scale consists of four dimensions, namely individual influence, inspirational motivation, intellectual stimulation, and individual consideration. Whereas the transactional leadership style scale consists of four dimensions, namely contingent reward, active exception management, passive exception management, and laissez-fair. These two types of leadership scale, measuring the perception of subordinate's 
assessment of the leadership of direct superiors involved in the company's transformation process both now and that has already taken place. A Cronbach's alpha coefficient of 0.90 has been obtained for the transformational leadership style and 0.91 for the transactional leadership style scale (Dewayani, 2014).

The summary of research instruments is depicted in Tables 1, 2, and 3 .

Table 1. Details of the Spread of Readiness for Change Scale Items

\begin{tabular}{rrrrr}
\hline No. & Dimension & Favorable & Unfavorable & Amount \\
\hline 1. & Promoting & $3,10,12,14$ & - & 4 \\
2. & Participating & $1,2,4,6,7$, & - & 6 \\
& & 9 & & \\
3. & Personal & - & $5,8,11,13$ & 4 \\
4. & valence & 15.16 .17 .18 & & 4 \\
& Change & & & \\
& efficacy & & 4 & 18 \\
\hline
\end{tabular}

Table 2. Distribution of Psychological Capital Scale Items

\begin{tabular}{clccc}
\hline No & Dimension & Favourable & Unfavourable & \\
. & & & Amount \\
\hline 1. & Hope & $13,14,15,16$, & - & 6 \\
2. & Efficacy & 17,18 & & \\
3. & Resilience & $19,20,4,5,6$ & - & 6 \\
4. & Optimism & $7,8,9,10,11$ & - & 6 \\
& & 23,24 & 12 & 6 \\
& Total & 23 & 1 & 24 \\
\hline
\end{tabular}


Table 3. Detail Distribution of Transformational and Transactional Leadership Scale Items

\begin{tabular}{|c|c|c|c|c|}
\hline \multicolumn{3}{|c|}{ Dimension } & No Item & Amount \\
\hline \multicolumn{5}{|c|}{ Transformational } \\
\hline \multicolumn{3}{|c|}{ - Inspirational Motivation } & $9,13,26,36$ & \\
\hline \multirow[t]{2}{*}{ - } & Idealized & Influence & $10,18,21,25$ & \\
\hline & Attribute & & 6.14 .23 .34 & \\
\hline & Idealized & Influence & $2,8,30,32$ & \\
\hline & Behavior & & $15,19,29,31$ & 20 \\
\hline \multicolumn{5}{|c|}{ - Intelectual Sumulation } \\
\hline \multicolumn{5}{|c|}{ - Individualized } \\
\hline \multicolumn{3}{|c|}{ Transactional } & $\begin{array}{l}4,22,24,27 \\
3,12,17,20\end{array}$ & \\
\hline \multicolumn{3}{|c|}{ - Contingent Reward } & \multicolumn{2}{|c|}{ - Active Management by } \\
\hline - & $\begin{array}{l}\text { Exception } \\
\text { Management } \\
\text { Passive } \\
\text { Laissez Faire }\end{array}$ & Exception & & \\
\hline Total & & & & 36 \\
\hline
\end{tabular}

Based on the three tables above, it can be concluded that the Spread of Readiness for Change Scale measuring instrument has 18 items, the Psychological Capital Scale has 24 items, and the Transformational and Transactional Leadership Scale has 36 items.

In this research, we used convergent validity and construct reliability tests that were analyzed by using SPSS 25 version and STATCAL statistical software. Data analysis methods in this research were used a mediation analysis technique to examine the mediator's signification of transformational leadership and transactional leadership in the relationship between psychological capital and readiness for change. 
Mediation analysis was performed with the help of the STATCAL software. The results of the validity and reliability tests mentioned above indicate that the four research instruments were declared valid and reliable, so the data obtained were worthy of further analysis.

\section{Hypothesis Testing}

In this research, we proposed two SEM models, namely the first model of transformational leadership and the second model of transactional leadership. In order to address hypothesis 1, confirmatory factor analysis (CFA) was used to test two different measurement models. Model 1 was distinguished and compares to three alternative models to test its relevance. Model 1 consisted of three latent variables, namely (1) readiness for change, (2) psychological capital, (3) transformational leadership style. All the latent variables in model 1 were allowed to correlate. Similarly to model 1, model 2 was constructed. Model 2 consisted of three latent variables, (1) readiness for change, (2) psychological capital, (3) transactional leadership style. After the data is collected and declared valid and reliable, it was then continued with the hypothesis test. The main hypothesis of this research, leadership styles (transformational and transactional latent variables) mediate the relationship between psychological capital and readiness for change. The hypothesis was tested with SEM, a structural equation modeling technique that is very cross-sectional, linear, and general. In SEM three forms of output can be shown, namely factor analysis, path analysis, and regression analysis.

Both models were analyzed using the STATCAL statistical program, and the results are as follows:

Hypothesis 1 was accepted, as the results indicated that the latent variables are correlated significantly. The results further suggest that model 1 fits the data best. It means that in the first model, transformational leadership can be role as a "partially mediator" between psychological capital and readiness for change. The estimate of transformational leadership as a mediator is 0.235 with a significance of $p=0.001$. This 
finding indicates that the perception of transformational leadership significantly fully mediated the relationship between psychological capital and readiness for change.

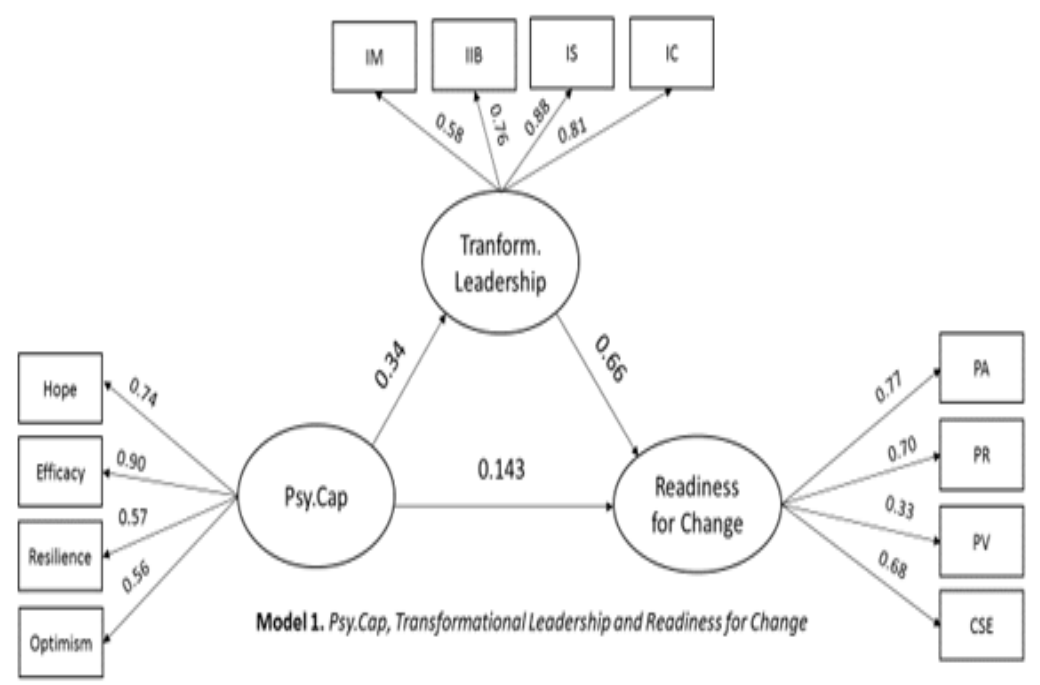

Hypothesis 2 indicated that the transactional leadership style mediates the relationship between psychological capital and readiness for change. Upon investigation of the correlational relationships between the variables, indirect effects were tested. Model 2 showed the indirect effects of transactional leadership style fully mediated the relationship between psychological capital and readiness for change. was accepted, as the results indicated that the latent variables are correlated significantly. The results further suggest that model 2 fits the data best. It mean that in the first 
model, transactional leadership can be role as a "partially mediator" between psychological capital and readiness for change.

The estimate of transactional leadership as a mediator is 0.419 with a significance of $\mathrm{p}=0.001$. This finding indicates that perceptions of transactional leadership significantly fully mediated the relationship between psychological capital and readiness for change.

While we compared the first model and the second model, the estimation of mediators 'perception of transactional leadership (0.419) is greater than the estimation of mediators' perception of transformational leadership (0.235). Based on the results of this research it can be concluded that the group of participants in this research (staff level) is more effective using the transactional leadership style than the transformational leadership style.

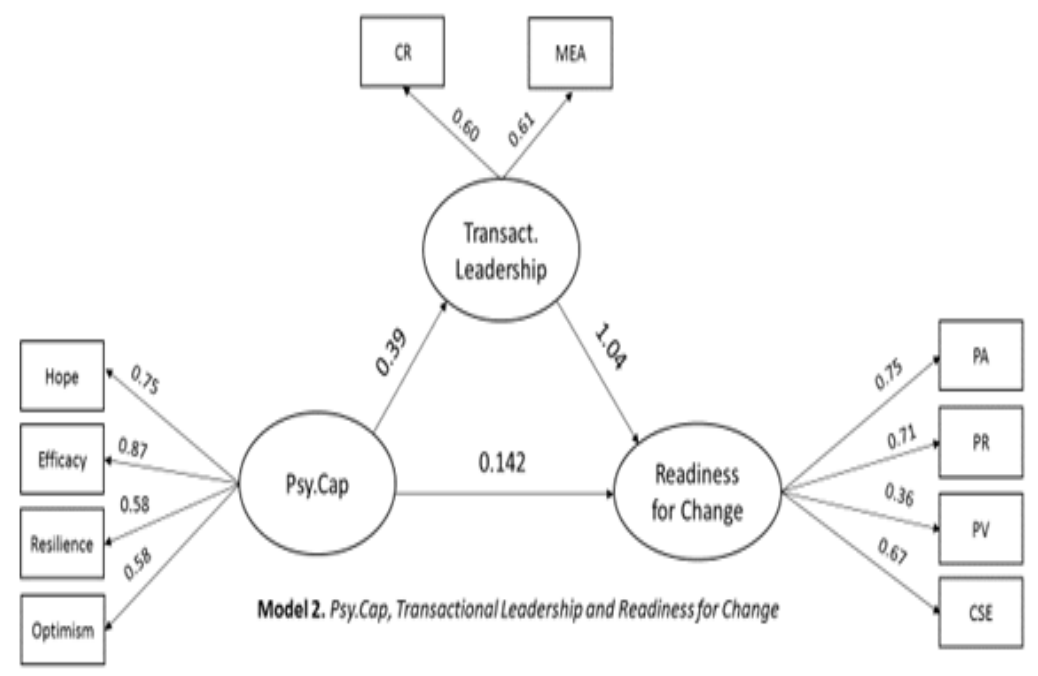

Vol. 28, No. 3 December 2020

(C) Centre for Indonesian Accounting and Management Research Postgraduate Program, Brawijaya University 


\section{DISCUSSION}

This research aimed to investigate the effects of leadership style (transformational and transactional) on the relationship between psychological capital and readiness for change. From this, the research hypothesized that: (1) psychological capital, transformational leadership, and readiness for change are correlated and (2) psychological capital has a full indirect effect on readiness for change via transactional and transformational leadership styles.

The results of this research confirm that psychological capital, leadership styles, and readiness to change have a correlational relationship, and previous research from a theoretical and empirical perspective supports the findings of this research, Kirrane (2017) shows that the ability of employees to respond effectively to changes is determined from the relationship between resources the psychological individual themselves and their perceptions of the social environment in the organization when change begins to be applied. Psychological resources of employees affect their interpretation of management support. Kirrane et.al (2017) research results also reinforce the statement that the impact of management support for change becomes stronger when employees have a strong psychological capital level as well.

Shin, Taylor, \& Sheo (2012) also reinforces the findings of this research. Organizational support (tangible or intangible) and psychological resilience have an influence on employee attitudes and behavior towards change. Employees with high psychological resilience tend to have a strong commitment to change because of the positive emotions they experience during organizational change.

Hypothesis 1 states that transformational leadership styles can mediate the relationship between psychological capital and readiness for change. Hypothesis 1 was accepted. Structural models show that transformational leadership partially mediates the relationship between psychological and readiness for change. The results of this research are in line with the results of research by Pranowo \& Prihatsanti (2016) who 
found that there was a significant positive relationship between transformational leadership styles and readiness to change for employees. This research supports previous research that leaders with transformational leadership styles are believed to be able to lead employees towards major changes in the organization globally (Sarros in Pranowo \& Prihatsanti, 2016). Leaders who use transformational leadership styles are believed to tend to increase the motivation and performance of followers by making them more aware of the importance of tasks in the organization, being a positive example for employees, and paying attention to the needs of followers who are higher (Stewart in Pranowo \& Prihatsanti, 2016).

Hypothesis 2 stated that the transactional leadership style would mediate the relationship between psychological capital and readiness for change. Hypothesis 2 was fully accepted. The structural model indicated that transactional leadership can fully mediate the relationship between psychological and readiness for change. The results of this research are in line with research by Veronika \& Prihatsanti (2017) which shows a comparison of subordinates to the relationship that exists between leaders and subordinates influencing changes. Nordin (2011) revealed that $44.1 \%$ of the variance in readiness for change was explained by emotional intelligence, organizational commitment, and transactional leadership behavior.

Transactional leadership styles can involve values, but they are relevant to the exchange process such as honesty, responsibility, and reciprocity. According to Bas et al. (in Purwanto, Bernato, Asbari, Wijayanti, \& Hyun, 2020) argues that the transactional leader's relationship with his subordinates is reflected in three things, the Leader knows what subordinates want and will explain what subordinates will get if the work is in accordance with hope. Leaders exchange efforts by subordinates in return. The leader is responsive to the subordinate's personal interests as long as the interests are proportionate to the value of the work done by the subordinate.

The SEM results confirmed that psychological capital indirectly influences readiness for change via transactional leadership. According to Avolio, Walumbwa, and Weber (2009), transactional leadership is "largely 
based on the exchange of rewards contingent on performance". Transactional leadership focuses on the leader-follower relationship. The research data shows the transactional leadership style seems to be greater and more is considered to have a positive influence on employee conditions. This condition can occur because the perceived style of the leader in accordance with the work environment depends on leadership skills to be able to influence employees to produce optimal performance. Wexley and Yukl (2003) assume that leadership is the process of using a positive influence on others.

In addition, the results of this calculation also show that transformational leadership can significantly be a mediator in the relationship between psychological capital and readiness for change. In line with the results of Sasmita's research (2019) which shows that transformational leadership variables have a greater influence on individual readiness for change than psychological capital variables. Abbasi's research (2017) found that one of the factors related to an individual's readiness for change is transformational leadership.

This research shows the level of position in the organizational hierarchy also influences. This research shows that at the staff level especially sacrificed proves that the transactional leadership style is more influential than the transformational leadership style.

Thus, in the process of organizational transformation, both leadership styles need to be applied depending on the group of employees that will be influenced. The lower the position, the more the need to apply transactional leadership style, the higher the position the possibility of the need for transformational leadership style.

\section{CONCLUSION}

The conclusion of this research is both transformational and transactional leadership significantly fully mediated the relationship between psychological capital and readiness for change. The estimated value of the mediator is the greatest in transactional leadership. Readiness 
for change is not only influenced by psychological capital and leadership perceptions. However, this is preliminary research, thus, it needs to be followed up with further studies in order to get the more comprehensive model of readiness for change. Furthermore, the business characteristics of each company are different, so it needs to be taken into consideration which model could be applied. 


\section{REFERENCES}

Abbasi, B. (2017). Transformational leadership and change readiness and a moderating role of perceived bureaucratic structure: an empirical investigation. Problems and Perspective in Management, 15(1), 35-44.

Armenakis, A. A., Harris, S. G., \& Mossholder, K. W. 1993. Creating readiness for organizational change. Human Relations, 46(6).

Armenakis, A. A., \& Bedeian, A. G. (1999). Organizational change: A review of theory and research in the 1990s. Journal of Management, 25(3), 293-315.

Armenakis, A. A., Jimmieson, N. L., \& Rafferty, A. E. (2013). Change readiness: a multilevel review. Journal of Management, 39(1), 110-135.

Avey, J. B., Wernsing, T. S., \& Luthans, F. (2008). Can positive employees help positive organizational change? Impact of psychological capital and emotions on relevant attitudes and behaviors. The Journal of Applied Behavioral Science, 44(1), 48-70.

Avolioi, B., Walumbwa, F., \& Weber, T. J. (2009). Leadership: Current theories, research, and future directions. Management Department Faculty Publications, 37.

Bank Indonesia mencanangkan gerakan nasional non tunai - Bank sentral Republik Indonesia (No. 16/ 58 /DKom). (2014). Retrieved from Departemen Komunikasi website:http://www.bi.go.id/id/ruang-media/siaranpers/Pages/sp_165814.aspx

Carina, J. (2017, September 6). Pemerintah ingin transportasi umum di Jakarta gunakan sistem non-tunai - Kompas.com. Retrieved October 20, 2017, from http://megapolitan.kompas.com/read/2017/09/06/12591841/pe merintah-ingin-transportasi-umum-di-jakarta-gunakan-sistemnon-tunai

Chaplin, J. P. (2006). Kamus lengkap psikologi. Jakarta, Indonesia: PT RajaGrafindo Persada.

Choi, M., \& Ruona, W. E. (2010). Individual readiness for organizational change and its implications for human resource 
and organization development. Human Resource Development Review, 10(1), 46-73.

Choi, M., \& Ruona, W. E. (2013). Individual readiness for organizational change. The Wiley-Blackwell Handbook of the Psychology of Leadership, Change, and Organizational Development, 331-345.

Choi, Y., \& Lee, D. (2014). Psychological capital, big five traits, and employee outcomes. Journal of Managerial Psychology, 29(2), 122-140.

Colman, A. M. (2015). A dictionary of psychology (4th ed.). Oxford, NY: Oxford University Press.

Cummings, T. G., \& Worley, C. G. (2009). Organization development and change (9th ed.). Mason, OH: South-Western College Pub.

Cunningham, C. E., Woodward, C. A., Shannon, H. S., MacIntosh, J., Lendrum, B., Rosenbloom, D., \& Brown, J. (2002). Readiness for organizational change: A longitudinal study of workplace, psychological and behavioural correlates. Journal of Occupational and Organizational Psychology, 75(4), 377-392. Fachruddin, D. F., \& Mangundjaya, W. H. (2012). The impact of workplace well-being and psychological capital, to the individual readiness for change. Proceedings 4th Asian Psychological Association, Jakarta, 5-7 July, 2012.

Feist, J., \& Feist, G. J. (2010). Teori kepribadian (7th ed.). Jakarta, Indonesia: Salemba Humanika.

Gibson, J. L., Ivancevich, J. M., Donnelly, Jr., J. H., \& Konopaske, R. (2012). Organizations: behavior, structure, processes (14th ed.). New York, NY: McGraw-Hill Irwin.

Gio, P. U., \& Caraka, R. E. (2018, October 18). Pedoman Dasar Mengolah Data Dengan Program Aplikasi Statistika Statcal. https://doi.org/10.31227/osf.io/796th

Hanpachern, C., Morgan, G. A., \& Griego, O. V. (1998). An extension of the theory of margin: A framework for assessing readiness for change. Human Resource Development Quarterly, 9(4), 339-350.

Heuvel, M., Demerouti, E., Bakker, A. B., \& Schaufeli, W. B. (2010). Personal resources and work engagement in the face of change. Contemporary Occupational Health Psychology, 1, 124-150.

Vol. 28, No. 3 December 2020

(c) Centre for Indonesian Accounting and Management Research

Postgraduate Program, Brawijaya University 
Holt, D., Feild, H., Harris, S., \& Armenakis, A. (2007). Readiness for organizational change. The Journal of Applied Behavioral Science, 43(2), 232.

Holten A. L., Brenner S.O. (2015). Leadership style and the process of organizational change. Leadership \& Organization Development Journal, Vol. 36 (1): 2-16.

Isabella, L. A. (1990). Evolving interpretations as a change unfolds: How managers construe key organizational events. Academy of Management Journal, 33(1), 7-41.

Istianah, I. (2016). Pengaruh Big Five personality pada readiness for change: Study pada awak kabin PT Garuda Indonesia(Unpublished doctoral dissertation). Universitas Gadjah Mada, Yogyakarta, Indonesia.

Ivancevich, J. M., $\quad$ Konopaske, R., \& Matteson, M. T. (2014). Organizational behavior and management (10th ed.).

Jabbarian, J., \& Chegini, M. G. (2016). The effect of perceived organizational support on employee resistance to change: A study on Guilan municipal staff. Journal of History Culture and Art Research, 5(4).

Jakarta Smart City. (2017, February). Membangun cashless society dengan sistem transaksi non tunai | Blog | Portal Jakarta smart city. Retrieved October 20, 2017, from http://smartcity.jakarta.go.id/blog/191/membangun-cashlesssociety-dengan-sistem-transaksi-non-tunai

John, O. P., Robins, R. W., \& Pervin, L. A. (2008). Handbook of personality: Theory and research (3rd ed.). New York, NY: The Cuilford Press.

John, O. P., \& Srivastava, S. (1999). The Big Five trait taxonomy: History, measurement, and theoretical perspectives. In Handbook of personality: Theory and research (2nd ed., pp. 102-138).

Jones, R. A., Jimmieson, N. L., \& Griffiths, A. (2005). The impact of organizational culture and reshaping capabilities on change implementation success: the mediating role of readiness for change. Journal of Management Studies, 42(2), 361-386.

Joniansyah. (2017, October 6). Ada Kartu E-Toll, Marga Mandalasakti Pastikan Tak PHK Karyawan - Bisnis Tempo.co. 
Retrieved October 20, 2017 , from https://bisnis.tempo.co/read/1022672/ada-kartu-e-toll-margamandalasakti-pastikan-tak-phk-karyawan

Kerlinger, F. N., \& Lee, H. B. (2000). Foundations of behavioral research(4th ed.). Fort Worth, TX: Harcourt College.

Kirrane, M., Lennon, M., O'Connor, C., \& Fu, N. (2017). Linking perceived management support with employees' readiness for change: the mediating role of psychological capital. Journal of Change Management.

Knowles, E. S., \& Linn, J. A. (2004). Resistance and persuasion. New York, NY: Routledge.

Kumar, R. (2005). Research metodology, a step by step guide for beginner. London, United Kingdom: Sage Publications.

Leonard, H. S., $\quad$ Lewis, R., Freedman, A. M., \& Passmore, J. (2013). The Wiley-Blackwell handbook of the psychology of leadership, change and organizational development. Malden, MA: Wiley-Blackwell.

Lizar, A. A., Mangundjaya, W. H., \& Rachmawan, A. (2015). The role of psychological capital and psychological empowerment on individual readiness for change. The Journal of Developing Areas, 49(5), 343-352.

Luthans, F., Avolio, B. J., Avey, J. B., \& Norman, S. M. (2007). Positive psychological capital: measurement and relationship with performance and satisfaction. Personnel Psychology, 60(3), 541-572.

Luthans, F., Luthans, K. W., \& Luthans, B. C. (2004). Positive psychological capital: beyond human and social capital. Business Horizons, 47(1), 45-50.

Luthans, F., \& Youssef, C. M. (2004). Human, social, and now positive psychological capital management: Investing in people for competitive advantage. Organizational Dynamics, 33(2), 143-160.

Luthans, F., Youssef, C. M., \& Avolio, B. J. (2007). Psychological capital: Investing and developing positive organizational behavior. Positive Organizational Behavior, 9-24.

Marketeers Editor. (2013, March 7). Studi kasus turn-around BUMN: PT Pos Indonesia. Retrieved November 7, 2017, from 
http://marketeers.com/studi-kasus-turn-around-bumn-pt-posindonesia/

Meaney, M., \& Pung, C. (2008). Mckinsey global survey results: Creating organizational transformations. London: McKinsey \& Company.

Ming-Chu, Y., \& Meng-Hsiu, L. (2015). Unlocking the black box: Exploring the link between perceive organizational support and resistance to change. Asia Pacific Management Review, 20(3), 177-183.

Nisfiannoor, M. 2009. Pendekatan Statistika Modern. Jakarta: Salemba Humanika

Noor, J. (2011). Metodologi penelitian: Skripsi, tesis, disertasi, dan karya ilmiah. Jakarta, Indonesia: Prenadamedia Group.

Nordin, N. (2011). The influence of emotional intelligence, leadership behaviour and organizational commitment on organizational readiness for change in higher learning institution. In Procedia - Social and Behavioral Sciences. https://doi.org/10.1016/j.sbspro.2011.11.217

Nugraheni, A. L. (2012). Pelatihan self efficacy untuk meningkatkan kesiapan dalam menghadapi perubahan pada karyawan PT PLN (Persero) PUSDIKLAT (Unpublished master's thesis). Universitas Indonesia, Depok, Indonesia.

Olaniyan, O. S., \& Hystad, S. W. (2016). Employees' psychological capital, job satisfaction, insecurity, and intentions to quit: The direct and indirect effects of authentic leadership. Revista de Psicología Del Trabajo y de Las Organizaciones, 32(3), 163171. https://doi.org/https://doi.org/10.1016/j.rpto.2016.09.003.

Oreg, S. (2003). Resistance to change: Developing an individual differences measure. Journal of Applied Psychology, 88(4), 680-693.

Prabowo, D. (2017, September 8). Transaksi non-tunai juga diterapkan di tol Jakarta-Tangerang - Kompas.com. Retrieved October 20, 2017 , from http://properti.kompas.com/read/2017/09/08/204022121/trans aksi-non-tunai-juga-diterapkan-di-tol-jakarta-tangerang.

Pranowo A. N. W., \& Prihatsanti U. (2016). Hubungan antara gaya kepemimpinan transformasional dengan kesiapan untuk 
berubah pada karyawan KPP Pratama Purworejo dan Temanggung DJP wilayah Jawa Tengah II. Jurnal Empati, Oktober 2016, Volume 5(4), 678-682.

Purwanto A, Bernarto I, Asbari M, Wijayanti L.M., Hyun C.C. (2020). Effect of transformational and transactional leadership style on public health centre performance. Journal of Research in Business, Economics, and Education, Vol. 2:1.

Puspasari N, Sukmawati A, Sumertajaya I. M. (2017). Leadership style, organizational communication, and employee participation to increase employee readiness in facing changes in business environment. Journal of Applied Management (JAM), Vol. 15, No. 4.

Radian N. N., \& Mangundjaya W. L. (2019). Individual readiness for change as mediator between transformational leadership and commitment affective to change. Jurnal Manajemen Aset Infrastruktur \& Fasilitas, Vol. 3, No. 1.

Ramphal, R. (2016). The relationship between personality traits, psychological capital and job performance among sales employees within an information, communication and technology sector (Master's thesis, University of South Africa, Pretoria, South Africa). Retrieved from http://uir.unisa.ac.za/handle/10500/22153

Ratya, M. P. (2017, October 31). Jurus PT KAI melajukan perubahan perkeretaapian. Retrieved November 7, 2017, from https://finance.detik.com/berita-ekonomibisnis/3708260/jurus-pt-kai-melajukan-perubahanperkeretaapian

Rifqi, M. (2016). Pengaruh dimensi kepribadian emotional stability terhadap kesiapan karyawan untuk perubahan organisasi dengan empowering leadership sebagai variabel pemoderasi (Master's thesis, Universitas Gadjah Mada, Yogyakarta, Indonesia).

Saksvik, I. B., \& Hetland, H. (2009). Exploring dispositional resistance to change. Journal of Leadership \& Organizational Studies, 16(2), 175-183.

Sapyaprapa, S., Tuicomepee, A., \& Watakakosol, R. (2013). Validation of psychological capital questionnaire in Thai employees. The Asian Conference on Psychology \& the

Vol. 28, No. 3 December 2020

(c) Centre for Indonesian Accounting and Management Research

Postgraduate Program, Brawijaya University 
Behavioral Sciences 2013 Official Conference Proceedings 2013, 394-399.

Saragih, E. H. (2015). Individual Attributes of Change Readiness: A Case Study at Indonesia State-owned Railway Company. Procedia - Social and Behavioral Sciences, 172, 34-41. https://doi.org/10.1016/j.sbspro.2015.01.332.

Sasmita, Ida.A.G.H.D. (2019). The effect of transformational leadership and psychological capital to individual readiness for change for employees in tourism development corporate. Journal PSIKODIMENSIA, Vol. 18, No.2.

Shin, J., Taylor, M. S., \& Seo, M.-G. (2012). Resources for change: The relationships of organizational inducements and psychological resilience to employees' attitudes and behaviors toward organizational change. Academy of Management Journal, 55(3), 727-748.

Smollan, R. K., Matheny, J. A., \& Sayers, J. G. (2010). Personality, affect, and organizational change: a qualitative study. Emotions and Organizational Dynamism, 6, 85-112.

Soumyaja D, Kamalanabhan T. J., \& Bhattacharyya S. (2018). Antecedents of employee readiness for change in the IT sector and the manufacturing sector: a comparative study. International Journal Human Resources Development and Management, Vol. 18, No. 3/4.

Sugiyono. (2007). Statistika untuk penelitian. Bandung: CV Alfabeta.

Tappin, R. M. (2014). Personality traits, the interaction effects of education, and employee readiness for organizational change: A quantitative study (10.13140/2.1.1978.4486) (Master's thesis). Retrieved from ProQuest Dissertations and Theses database. (10.13140/2.1.1978.4486).

Ul-Haq M. A., Kuchinke K. P. (2016). Impact of leadership style on employees' attitude towards their leader and performance: Empirical evidence from Pakistani banks. Future Business Journal 2: 54-64.

Veronika, T. \& Prihatsanti, U. (2017). Hubungan antara leader member exchange dengan kesiapan untuk berubah pada pegawai universitas tidar di magelang. Jurnal empati, 6(1), 407-410. 
Wexley, K.N. \& Yukl, G. A. (2003). Perilaku Organisasi dan Psikologi Personalia. Jakarya: PT. Rineka Cipta. 